\title{
Modelling Co-creation Ecosystem for Public Open Spaces
}

\author{
Aelita Skarzauskiene ${ }^{1(\bowtie)}$, Monika Maciuliene ${ }^{1}$, \\ and Petja Ivanova-Radovanova ${ }^{2}$ \\ 1 Mykolas Romeris University, Vilnius, Lithuania \\ \{aelita, maciuliene\}@mruni.eu \\ 2 Association for Integrated Development and Sustainability, Sofia, Bulgaria \\ petjaivanova@gmail.com
}

\begin{abstract}
Co-creation can be defined as the involvement of citizens in the initiation and/or the design process of public services in order to (co)create beneficial outcomes and value for society. Mediated public open spaces are ideal environments for co-creation to emerge due to the involvement of the community and ICT in the knowledge creation. The aims of the research presented in the chapter are two-fold: to conduct a mapping activity in order to collect the insights on civic technologies promoting the creation of open public spaces through the use of ICT and to define the critical dimensions in designing cocreative ecosystems. The mapping strategy was conducted by evaluating the civic technologies in Lithuania and Bulgaria. The insights from the empirical exercise allow to draw managerial and organizational recommendations for strengthening the collective efforts of citizens, IT developers, public and governmental institutions in creating open, inclusive and reflective open public spaces.
\end{abstract}

Keywords: Co-creation - Civic technologies $\cdot$ Community ·

Citizen empowerment

\section{Introduction}

In current societal settings influenced by globalization and ICT use, citizen engagement in development of public spaces should be approached holistically. Co-creation entails connections and collaboration in generation of added value for the involved actors (Alves 2013; Lönn and Uppström 2015). Mediated open spaces are ideal environments for the co-creation to emerge due to the involvement of entire community and information communication technologies in knowledge creation or aggregation. Co-creation offers an interesting perspective, as it enables the integration of a range of ICTmediated and offline participatory methods and creates a shared domain between professionals and citizens. In its optimal form, co-creation has the dual benefit of reducing public sector costs and increasing stakeholder satisfaction (Gouillart and Hallett 2015). Co-creation of public services can lead amongst other to better allocation of resources (Cruickshank and Deakin 2011), enhance effectiveness (Jan et al. 2012), 
reduce service quality gaps and planning mistakes (Linders 2012) and higher transparency (Bradwell and Marr 2008). Several authors (Cassia and Magno 2009; Skidmore et al. 2006) indicate that co-creative approaches increase the trust of citizens in public organizations. Recent literature within the co-creation of public spaces highlights the benefits collaboration brings by providing various examples of innovative projects and initiatives that have engaged citizens and had successful outcomes (Giest et al. 2016; Jacobsen 2016).

However, there is a relatively little research on the specific groups of activities that should be undertaken in order to enhance the co-creative capacity of various initiatives. Understanding what makes initiatives co-creative could lead to better design and management of projects. The aim of this chapter is to offer insights on the critical dimensions of co-creative ecosystems enhancing public open spaces based on the previous theoretical insights and empirical investigations. The ecosystem in this chapter refers to an interdependent social system of actors, organizations, material infrastructures, and symbolic resources that can be created in technology-enabled, information-intensive social systems. According to Harrison et al. (2012), “ecosystems are naturally occurring phenomena and the metaphor may be applied to any existing socio-technical domain, they can also be seeded, modelled, developed, managed, that is, intentionally cultivated for the purpose of achieving a managerial and policy vision."

The object of analysis in this framework are the civic technology platforms. It refers to the extendible platforms and applications that enable citizens to connect and collaborate with each other and with the government (Clarke 2014). The scope of the concept is wide and applicable in defining ICT-enabled technologies aimed at generation of value for the public ranging from online transparency and accountability initiatives to e-city applications. The rapid transformation of the society influenced by digital upheaval, budgetary pressures and evolving understanding of the citizen role in the workings of governments lead to a collaborative governance approach expressed in the literature on Open Government and Government 2.0 (e.g. Meijer et al. 2012; Uppström 2014). Such understanding is based on principles of collaboration, transparency and participation. Hence, in the context of proposed framework, the civic technologies are understood as the public services provided by non-governmental entities such as NGOs, educational organizations, individual citizens or grassroot movements.

Over the last decades, leading business and public management scholars and practitioners have highlighted the interactive and networked nature of the value creation both in business and in public sectors (Galvagno and Dalli 2014; Stembert and Mulder 2012). The new channels of communication and information flow enable the innovative involvement of the broader groups of society in collaborative activities in the shorter amounts of time. Hence, the authors develop a theoretically-oriented framework for conceptualizing co-creative ecosystems aimed at the enhancement of public spaces by evaluating civic technologies tackling issues related to public spaces in Lithuania and Bulgaria. 


\section{Co-creative Ecosystems: Theoretical Influences and Conceptual Analysis Framework}

The section explores theoretical influences of the conceptual analysis framework and details the logics and elements of the model. The conceptual models help to clarify what is known and unknown about the system and are key in interpreting research results. The framework is built according to the guidelines put forward by Jabareen (2009) summarized in four main directions: (1) every concept has an irregular contour defined by its components; (2) every concept contains components originating from other concepts, (3) every concept is considered as the point of coincidence, condensation, or accumulation of its own components, and (4) every concept must be understood relative to its own components, to other concepts and to the problem it is supposed to resolve. In developing co-creative ecosystem framework, the authors have expanded on previous works of Service Science approach to co-creation and PPC analysis framework suggested by Warburton et al. (2010) aiming at evaluation of the success of various initiatives.

The Service Science theoretical approach provides the ecosystem logic for conceptual model and allows to understand the value co-creation processes in a holistic manner (Aladalah and Lee 2015; Lusch et al. 2008; Sterrenberg 2017). According to Meynhardt et al. (2016), most investigations on co-creation focus on micro and collective-macro levels. Systemic approach is often missing, and isolated investigations lead to incomplete research outcomes. Researchers at IBM and University of Cambridge suggest Service Science as an alternative method and research direction to discover underlying components of complex systems and the way they can be combined (IfM and IBM 2008). Hence, the it provides a much needed clarity and guidance for those wanting to apply principles of co-creation in managing organizations. The central concept of the Service Science as is a service ecosystem. It consists of several or many service systems connected by a network and Service Science focuses on value co-creation amongst them. Service system can be defined as dynamic configuration of people, technologies and organizations and their ecosystem can be defined as selfadjusting system of resource-integrating contributors connected by shared structures, social rules and mutual value creation (Akaka et al. 2013: 161).

In Service Science perspective, the value is created through three interrelated and cyclical processes in service systems (Goda and Kijima 2015: 85): resource integration, networking and service exchange. The Service Science suggests that value emerges when a number of entities work collectively to create mutual benefits by granting access to one another's resources including people, technologies, organizations and information. Interacting entities form service ecosystems consisting of several or many service systems connected by a network. The entities cannot create and deliver value alone; they can only propose value offerings to the other actors in the network and in this way co-create the value.

The elements of the framework are based on the model suggested by Warburton et al. (2010) who proposed that success of initiative depends on three elements - the process (how), the purpose (why) and the context (when, where) - the PPC framework. The PPC framework has been used in analysing open governance intelligence 
(Krimmer et al. 2016), strategic change in governance systems (Hamann 2009), ICTenabled social changes on community/societal level (Pozzebon and Diniz 2012), and organizational changes (Armenakis and Bedeian 1999). Figure 1 "Conceptual Analysis Framework for Co-Creative Ecosystems" illustrates the elements and the logics of the framework. Below detailed explanation of the framework elements is provided.

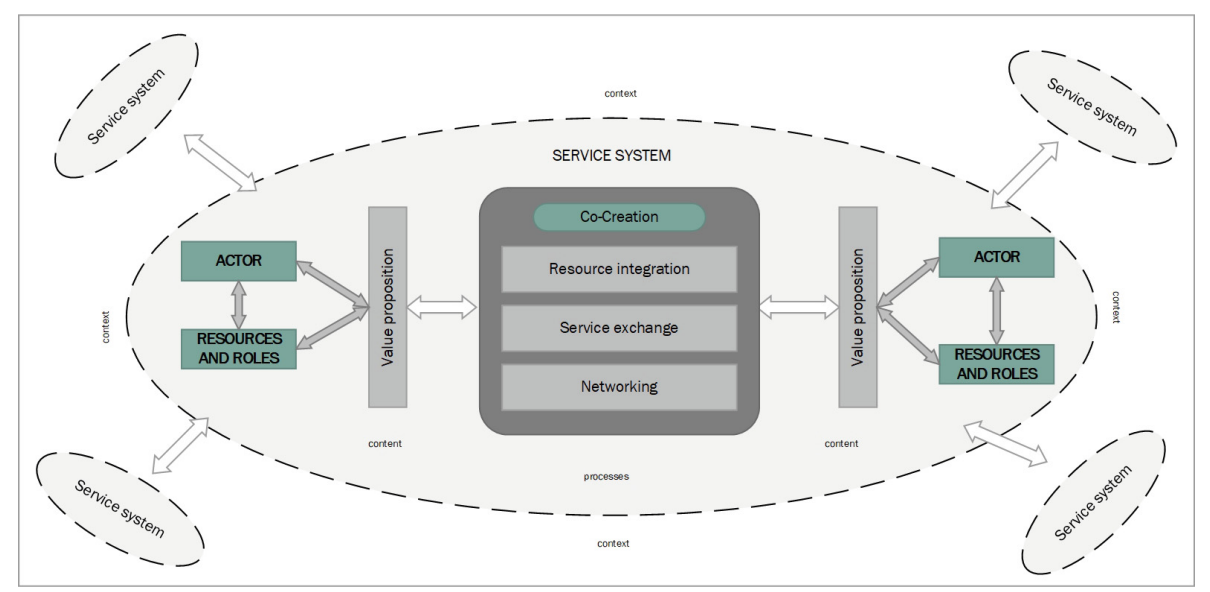

Fig. 1. Conceptual analysis framework for co-creative ecosystems. Source: developed by authors, 2017

The first, process, element is dedicated to analysis of the actors involved in cocreation processes - their roles and dynamics. (Voorberg et al. 2009) suggest that the success of co-creative initiatives depends highly on the position and interests of the involved stakeholders. Cobo (2012) states that "although collaboration has the potential to produce powerful results, not all collaborations realize this potential. Many collaborations fail to produce innovative solutions or balance stakeholder concerns, and some even fail to generate any collective action whatsoever". Brown and Osborne (2012) suggest that the collaboration efforts should be evaluated based on interests, goals and motivations of diverse actors involved. McNutt et al. (2016) suggests that the sustainability of co-creative initiatives in public sector depends on the networked relationships between the business entities, NGOs and more informal groups of citizens. The motivation to create partnerships comes from the recognition that collaborating organizations can accomplish what each partner cannot accomplish alone by maximizing the influence, creating collective resources and removing duplication of the efforts.

The purpose element examines reasons why the initiatives have been established. Earlier work by academics and practitioners (Emerson et al. 2011; Hepburn 2015) on evaluating the co-creative initiatives focused primarily on the process issues, largely ignoring the purpose of such projects. The predominant method was to examine best practice case studies based on a set of principles, and the process was often considered to be an end in itself rather than a means to an end. However, more attention needs to 
be paid to the content of the initiatives and contextual factors that can mitigate the effectiveness of co-creation and its outcomes in terms of the decision-makers or the participants. The design and structure of technological solutions can give impetus to the purposeful development towards common community good. On the other hand, if social values of the citizens acting in a collective environment are not aligned or coordinated and if technological decisions are implemented without scientific reasoning in an immature environment, these technological solutions can accelerate negative aspects of ICT and distance even more from the desirable goal of an inclusive community (Skaržauskienè et al., 2015). The context element refers to the contextual influences of the co-creative initiatives such as social context and the networks of collaboration and association, scale and type of the issue addressed.

The PPC elements allow to discuss the civic technologies in-depth and enables the comparison between varying technological solutions. The conceptual framework enhances existing research methods and models into the new context of people, places and technology by employing the logics of ecosystem. Identified dimensions should not be considered independently of one another. Such analysis framework will help to come to more comprehensive assessment of what makes such initiatives successful in engaging citizens and in enhancing public spaces.

\section{Empirical Investigations on Co-creative Ecosystems and Civic Technologies in Lithuania and Bulgaria}

The conceptual analysis framework was used to evaluate civic technologies (online platforms and applications) oriented towards enhancement of public spaces in Lithuania and Bulgaria with the task to provide managerial and organizational recommendations for strengthening the collective efforts of citizens, IT developers, public and governmental institutions in creating open, inclusive and reflective open public spaces. The methods of content mapping and analysis were applied. The mapping activity aimed at collection of data on the co-creative ecosystems in Lithuania and Bulgaria in order to develop insights on involved actors, type of co-creative activities and objectives and to determine the linkages and synergy between the actors. To achieve this goal, the method of online content analysis has been employed. The research process can be divided in to four stages: sample selection, design of the data collection template, data collection and evaluation of the results.

The platforms in the sample were selected according the selection criteria: (1) ICTenabled and interactive. The platforms employ ICT solutions (i.e. online forums, ideation platforms) to be more open, inclusive and collaborative; (2) Based in Lithuania and Bulgaria. The platform activities aim to improve public spaces in Lithuania and Bulgaria; (3) Orientation. The platforms may be for non-profit as well as for profit; but their overall objectives should serve the community and improve the public spaces; (4) Contributors. Selected platforms have capabilities to involve a large number of members in making decisions or proposing ideas; (5) Duration. Projects with a minimum of 1 year of activity; (6) Data availability. Goals, metrics, initiators are listed on platform website; (7) Collective action. Projects allows collaboration between citizens and/or business and/or NGO's and/or governments. The sample was gathered through a 
review of the previous studies on civic technologies, European funding databases, municipal websites, popular blogs and through original Google searches on array of civic engagement related terms in Lithuanian and Bulgarian. Based on the listed criteria, the sample includes 13 civic tech initiatives oriented towards improvement of public spaces in Lithuania and Bulgaria. The sample and details of the initiatives are provided in the Table 1 below.

Table 1. Sample of civic tech initiatives

\begin{tabular}{|c|c|c|c|c|}
\hline $\begin{array}{l}\text { Name of the } \\
\text { initiative }\end{array}$ & Code & $\begin{array}{l}\text { Country } \\
\text { of } \\
\text { operation }\end{array}$ & URL address & Initiator \\
\hline ABLE & P1 & Bulgaria & $\begin{array}{l}\text { www. } \\
\text { ablebulgaria.org/ } \\
\text { en/ }\end{array}$ & $\begin{array}{l}\text { Community of entrepreneurial } \\
\text { young people }\end{array}$ \\
\hline Archmap.lt & $\mathrm{P} 2$ & Lithuania & www.archmap.lt & $\begin{array}{l}\text { "Architektūros centras", } \\
\text { Lithuanian Architects' Association } \\
\text { and "Architektūros fondas" }\end{array}$ \\
\hline asLietuvai.lt & $\mathrm{P} 3$ & Lithuania & www.asLietuvai.lt & Individual initiative \\
\hline Cultural cosmos & P4 & Bulgaria & $\begin{array}{l}\text { https:// } \\
\text { culturalcosmos. } \\
\text { com/cultural- } \\
\text { cosmos/ }\end{array}$ & $\begin{array}{l}\text { Team of "Kosmos" cinema, the } \\
\text { city of Plovdiv }\end{array}$ \\
\hline $\begin{array}{l}\text { Kelionės kultūros } \\
\text { keliais }\end{array}$ & P5 & Lithuania & $\begin{array}{l}\text { http:// } \\
\text { idomiausiosvietos. } \\
\text { lt/keliones }\end{array}$ & "Paveldo projektai" \\
\hline Kurgyvenu.lt & P6 & Lithuania & www.kurgyvenu.lt & “CodeIN" \\
\hline mesDarom.lt & P7 & Lithuania & www.mesdarom.lt & "Mes Darom" \\
\hline Millenium & P8 & Bulgaria & $\begin{array}{l}\text { www.millennium. } \\
\text { bg }\end{array}$ & Foundation Millenium \\
\hline Nemasinis.1t & P9 & Lithuania & www.nemasinis.lt & Individual initiative \\
\hline $\begin{array}{l}\text { pamatykLietuvoje. } \\
\text { lt }\end{array}$ & P10 & Lithuania & $\begin{array}{l}\text { www. } \\
\text { pamatykLietuvoje. } \\
\text { lt }\end{array}$ & Individual initiative \\
\hline $\begin{array}{l}\text { Transformatory } \\
\text { Association }\end{array}$ & P11 & Bulgaria & $\begin{array}{l}\text { www. } \\
\text { transformatori.net/ } \\
\text { en }\end{array}$ & Group of young architects \\
\hline Tuk Tam & P12 & Bulgaria & https://tuk-tam.bg & $\begin{array}{l}8 \text { young people used to live and } \\
\text { study abroad together with } \\
\text { Back } 2 \text { BG }\end{array}$ \\
\hline Uspelite & P13 & Bulgaria & http://uspelite.bg/ & Superhosting.bg \\
\hline
\end{tabular}

Source: developed by authors, 2017

During the second stage, data collection template was designed based on the theoretical framework and publicly available data on selected platforms. The template is a necessary tool in order to make data collection process uniform across platforms and to enable patterning. The template is divided into 3 sections based on the elements in the 
theoretical framework: (1) purpose element (goals, operation type, context); (2) process element (users, initiators, funding, partners, developers, resources); (3) context element (networks of collaborators, dynamics of collaboration). The fieldwork was done during April-May 2017. Some categories were pre-defined based on previous chapters in order to help data structuration and evaluation. Third stage of the empirical study is data collection including systemic coding of textual content and semantic themes found on the platforms by reviewing uploaded documents, outgoing links, social media accounts, user activity and media mentions. The last stage involved evaluation and synthesis of the results. Comparison of the research data across the cases led to the generation of the insights on the co-creative ecosystems.

Described method has several limitations which need to be mentioned. The first limitation is the heterogeneity of Internet data which predetermined by the differences in content, user interfaces, semantics, structure, etc. The differences make it difficult for the researchers collecting online data (Bouchkhar 2013). Another limitation is the sample of platforms. It has to be mentioned that the sample is not representative of the universe of civic technologies. Moreover, due its limited size, it does not present statistical significance. However, as the first exercise in differentiating the building blocks of co-creative ecosystems, it can be considered as an effort of structuring the sample.

\section{Analysis and Discussion of the Empirical Study Results}

The analysis of the research outputs aimed at unfolding the purpose dimension (the goals, operation type) of civic technologies aimed at enhancement of public spaces in Lithuania and Bulgaria allowed to elaborate the types of value propositions offered for the actors in the ecosystem. Knowing why individuals and organizations build platforms, and why citizens participate in them, can guide the organizations and civic leaders in fostering ICT-enabled platforms. The findings of analysis are illustrated in Table 2 "The Results on Purpose Dimension".

The goals, orientation and operation type of the platforms analysed provide insights on the value the platforms aim to cumulate. The analysis allowed to cluster the Civic Technologies based on the changes they are seeking in the society expressed through the notion of value proposition. Six types of value propositions were identified in the sample: economic, self-expression, knowledge/information, status, functional and network. Economic value proposition refers to the pursuit of profit, savings, return of investments for the actors involved in service system. It was identified in four platforms. Self-expression value proposition was identified in all 13 platforms and deals with contribution to the society, expression of views by the actors of service system. Knowledge/information proposition was also observed in all the sample platforms and refers to the aim of information dissemination between the members of service system. The status value proposition refers to the pursuit of feeling more important by the actors in the system and is expressed in nine platforms. Ten platforms offer network value proposition expressed through the goals of closer partnerships, mutual benefits, increased impact, access to greater pool of partners and supporters. The last value proposition, functional, was identified in all of the sample platforms and refers to the core functional benefits the service provides to the members of society. 
Table 2. The results on purpose dimension

\begin{tabular}{|c|c|c|}
\hline $\begin{array}{l}\text { Name of the } \\
\text { platform }\end{array}$ & Goals of the platform & Value propositions identified \\
\hline ABLE & $\begin{array}{l}\text { "...The mission is to develop a civil } \\
\text { society, inspire leadership, and spread } \\
\text { entrepreneurial culture in Bulgaria; } \\
\text { website, social network, offline events } \\
\text { organization, project. Initiators met } \\
\text { during participation in the Bulgarian } \\
\text { Young Leaders Program (BYLP) and } \\
\text { in } 2011 \text { decided to start a non-profit to } \\
\text { serve as a platform for our ideas and } \\
\text { for positive change in Bulgaria. Since } \\
\text { then - with the proportional increase in } \\
\text { our members - our projects, our } \\
\text { influence, and their successes in } \\
\text { Bulgarian society have been growing } \\
\text { as well..." }\end{array}$ & $\begin{array}{l}\text { Knowledge/information; } \\
\text { functional; self-expression; } \\
\text { network; status }\end{array}$ \\
\hline Archmap.lt & $\begin{array}{l}\text { "...To present Lithuanian architecture } \\
\text { and public spaces to wider audiences in } \\
\text { order to increase the public interest to } \\
\text { get to know the architectural heritage. } \\
\text { To represent Lithuanian architecture by } \\
\text { expanding the scope from the cities to } \\
\text { lesser explored regions..." }\end{array}$ & $\begin{array}{l}\text { Knowledge/information; } \\
\text { functional; self-expression; } \\
\text { status }\end{array}$ \\
\hline asLietuvai.lt & $\begin{array}{l}\text { "...To achieve the breakthrough of } \\
\text { Lithuanian thinking and mentality from } \\
\text { destruction to flourishing..." }\end{array}$ & $\begin{array}{l}\text { Knowledge/information; } \\
\text { functional; self-expression; } \\
\text { network }\end{array}$ \\
\hline Cultural cosmos & $\begin{array}{l}\text { "...Create platform for culture and } \\
\text { society in partnership with } \\
\text { Municipality of the city of Plovdiv; } \\
\text { Enhancement civil society; Networking } \\
\text { and partnership with cultural operators } \\
\text { and institutions from BG and } \\
\text { Europe..." }\end{array}$ & $\begin{array}{l}\text { Knowledge/information; } \\
\text { functional; self-expression; } \\
\text { network; status }\end{array}$ \\
\hline $\begin{array}{l}\text { Kelionès kultūros } \\
\text { keliais }\end{array}$ & $\begin{array}{l}\text { "...To stimulate and motivate the need } \\
\text { to travel in Lithuania, explore new } \\
\text { regions and cultural objects..." }\end{array}$ & $\begin{array}{l}\text { Knowledge/information; } \\
\text { functional; self-expression }\end{array}$ \\
\hline Kurgyvenu.lt & $\begin{array}{l}\text { "...To help the owners, sellers, buyers, } \\
\text { brokers, renters and other interest } \\
\text { parties to make real-estate related } \\
\text { decisions easier and more } \\
\text { intelligent..." }\end{array}$ & $\begin{array}{l}\text { Knowledge/information; } \\
\text { functional; economic; self- } \\
\text { expression; network; status }\end{array}$ \\
\hline mesDarom.lt & $\begin{array}{l}\text { "...Creation of sustainable society by } \\
\text { uniting individuals, families, business, } \\
\text { initiatives and other entities in order to } \\
\text { preserve the country and public spaces } \\
\text { for future generations..." }\end{array}$ & $\begin{array}{l}\text { Knowledge/information; } \\
\text { functional; self-expression; } \\
\text { network; status }\end{array}$ \\
\hline
\end{tabular}


Table 2. (continued)

\begin{tabular}{|c|c|c|}
\hline $\begin{array}{l}\text { Name of the } \\
\text { platform }\end{array}$ & Goals of the platform & Value propositions identified \\
\hline Millenium & $\begin{array}{l}\text { "...Development of sustainable and } \\
\text { balanced regions in Bulgaria and } \\
\text { Europe; Enhancement of suitable } \\
\text { conditions for economic development } \\
\text { and employment in Support for } \\
\text { economic development and social } \\
\text { cooperation between regions in } \\
\text { Bulgaria and Europe. Support and } \\
\text { creation of suitable environment for } \\
\text { decentralization of social services in } \\
\text { Bulgaria..." }\end{array}$ & $\begin{array}{l}\text { Knowledge/information; } \\
\text { functional; self-expression; } \\
\text { network }\end{array}$ \\
\hline Nemasinis.lt & $\begin{array}{l}\text { "...To collect and visualize interesting } \\
\text { Lithuanian public objects that are } \\
\text { outside the scope of traditional } \\
\text { travellers and explorers due to the } \\
\text { limited accessibility and bad } \\
\text { conditions. It allows to expand the } \\
\text { understanding about the } \\
\text { surroundings..." }\end{array}$ & $\begin{array}{l}\text { Knowledge/information; } \\
\text { functional; self-expression }\end{array}$ \\
\hline $\begin{array}{l}\text { pamatykLietuvoje. } \\
\text { lt }\end{array}$ & $\begin{array}{l}\text { "...To motivate and stimulate internal } \\
\text { tourism, find new interesting spaces } \\
\text { and places, share the knowledge and } \\
\text { experiences..." }\end{array}$ & $\begin{array}{l}\text { Knowledge/information; } \\
\text { functional; self-expression; } \\
\text { network; status }\end{array}$ \\
\hline $\begin{array}{l}\text { Transformatory } \\
\text { Association }\end{array}$ & $\begin{array}{l}\text { "...The association aims to set good } \\
\text { practice, realizing common initiatives } \\
\text { with the specialized educational } \\
\text { schools in the constructional and } \\
\text { architectural field for improving the } \\
\text { educational process..." }\end{array}$ & $\begin{array}{l}\text { Knowledge/information; } \\
\text { functional; self-expression; } \\
\text { network; status }\end{array}$ \\
\hline Tuk Tam & $\begin{array}{l}\text { "...Community of knowledgeable, } \\
\text { initiative and well educated Bulgarians } \\
\text { from all over the world. We implement } \\
\text { projects and organize events in the } \\
\text { spheres of professional development, } \\
\text { education and social economy in } \\
\text { Bulgaria and abroad..." }\end{array}$ & $\begin{array}{l}\text { Knowledge/information; } \\
\text { functional; self-expression; } \\
\text { network }\end{array}$ \\
\hline Uspelite & $\begin{array}{l}\text { "...Since } 2015 \text { it became the most } \\
\text { popular positive media in Bulgaria..." }\end{array}$ & $\begin{array}{l}\text { Knowledge/information; } \\
\text { functional; self-expression; } \\
\text { network }\end{array}$ \\
\hline
\end{tabular}

Source: developed by authors, 2017 
The process dimension refers to the of individuals and organizations participating in the service ecosystem, their roles and resources. The mapping activity allowed to identify nine groups of actors involved in co-creative ecosystems-governmental entities, citizens, private organizations, NGOs, media, specialists, associations, public organizations and international organizations. The content analysis (see Table 3 below) of the user groups as defined by initiators showed that, in most cases, initiators define the user groups employing very abstract terms. Also, the 'official' focus is on the citizens (expressed variously e.g. young people, habitants, etc.). Non-citizen actor groups are mostly left out of the descriptions of the platform orientation. Hence, indepth review of the platform content, the services they provide, funding sources and strategic documents was conducted and resulted in identification of eight actor groups citizens, governmental organizations, NGOs, business organizations, media organizations, public organizations, associations, international organizations - which participate in the ecosystem directly and indirectly.

Table 3. The results on process dimension

\begin{tabular}{|c|c|c|}
\hline $\begin{array}{l}\text { Name of the } \\
\text { platform }\end{array}$ & $\begin{array}{l}\text { Types of } \\
\text { initiators }\end{array}$ & Target groups identified by the initiators \\
\hline ABLE & $\begin{array}{l}\text { Individual } \\
\text { citizens }\end{array}$ & “...Young people and urban development professionals..." \\
\hline Archmap.lt & $\begin{array}{l}\text { NGO and } \\
\text { association }\end{array}$ & $\begin{array}{l}\text { "...Professionals, amateurs, young and old, anyone } \\
\text { interested in architecture..." }\end{array}$ \\
\hline asLietuvai.lt & $\begin{array}{l}\text { Individual } \\
\text { citizens }\end{array}$ & "...Young and talented Lithuanian all around the world..." \\
\hline Cultural cosmos & $\begin{array}{l}\text { Individual } \\
\text { citizens }\end{array}$ & $\begin{array}{l}\text { "...Citizens of the city of Plovdiv, cultural industries with } \\
\text { focus on young people and artists in the first stage of their } \\
\text { development..." }\end{array}$ \\
\hline $\begin{array}{l}\text { Kelionès kultūros } \\
\text { keliais }\end{array}$ & NGO & "...everyone interested..." \\
\hline Kurgyvenu.lt & Business & “...travellers, teachers, lecturers, travel guides, families..." \\
\hline mesDarom.lt & NGO & $\begin{array}{l}\text { "...individuals, families, communities, governmental } \\
\text { institutions, businesses, initiatives and other movement..." }\end{array}$ \\
\hline Millenium & NGO & “...NGOs, local authorities, business, local people..." \\
\hline Nemasinis.lt & $\begin{array}{l}\text { Individual } \\
\text { citizens }\end{array}$ & “...everyone..." \\
\hline $\begin{array}{l}\text { pamatykLietuvoje. } \\
\text { lt }\end{array}$ & $\begin{array}{l}\text { Individual } \\
\text { citizens }\end{array}$ & "...everyone interested in travelling" \\
\hline $\begin{array}{l}\text { Transformatory } \\
\text { Association }\end{array}$ & $\begin{array}{l}\text { Individual } \\
\text { citizens }\end{array}$ & "...Young people and urban development professionals..." \\
\hline Tuk Tam & $\begin{array}{l}\text { Individual } \\
\text { citizens }\end{array}$ & $\begin{array}{l}\text { "...Young and well educated people in Bulgaria and } \\
\text { abroad..." }\end{array}$ \\
\hline Uspelite & $\begin{array}{l}\text { Individual } \\
\text { citizens }\end{array}$ & “...Young people...” \\
\hline
\end{tabular}

Source: developed by authors, 2017 
Six roles of the actors involved in the processes were identified - initiators, users, contributors, partners, sponsors and intermediaries. Figure 2 below illustrates the connections between the actors in the analyzed ecosystems. Initiators start the platforms by contributing their individual and organizational resources in terms of time, know-how, finances, etc. The roles identified can be filled by any of the actor groups identified. Meaning that the businesses can be initiators, users, contributors, initiators, partners and sponsors of the platforms. The same applies to the citizens and other actor groups. The role of the user refers to the actors using the platform and receiving ICTenabled service. The role of the contributor is closely related to the role of user. However, it is more interactive and refers to more interactive collaboration efforts by means of suggesting ideas, voting, reporting issues, communicating with other contributors and other ways of creating content beneficial for the active processes of the platform. The role of partner is to share operant resources with platform initiators and managers. The role refers to mutually beneficial relationships which are developed without losing autonomy of individual actors. The Sponsors provide financial resources for enabling platform activities. The sponsoring can happen in number of ways through governmental, business funding or citizens backing up the platforms they find important.

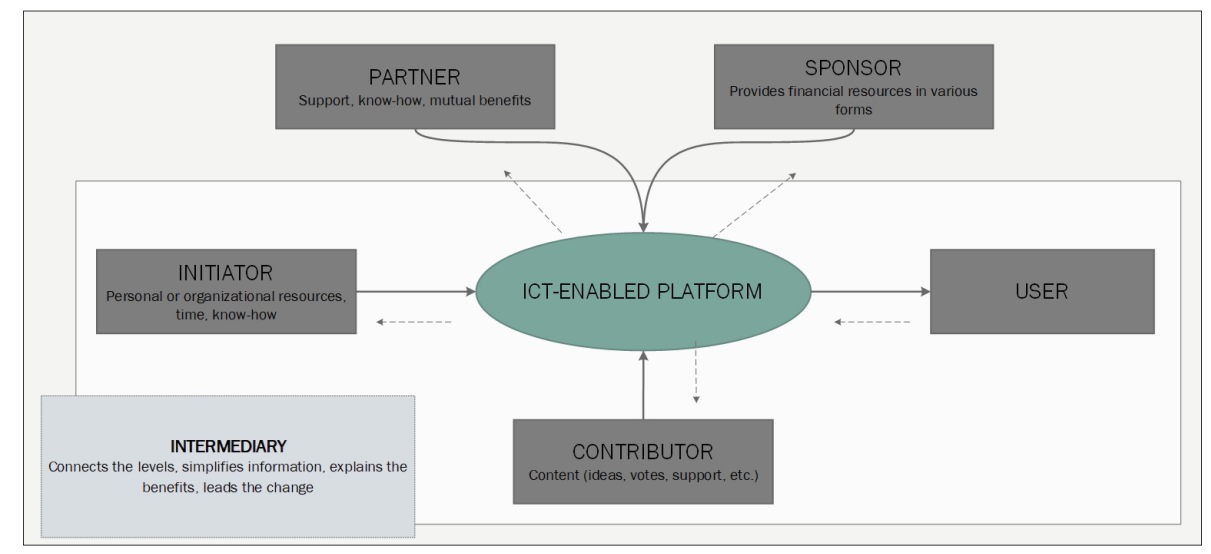

Fig. 2. Dynamics and roles of actors in the co-creative ecosystem. Source: developed by authors, 2017

The role of intermediary refers to actors connecting different actors in the ecosystem. For the society to evolve being more open and engaged, not all citizens have to be active, not all organizations have to be active - but there is need for intermediaries, civic leaders, active citizens who could translate the importance of active citizenship, transparency, translate the data and make it easier for citizens and governments to cooperate. The role of intermediary mostly refers to the individual actors, mostly specialists with the skills and knowledge in the fields of IT, open data, and governmental processes. The role of intermediary is especially relevant in the 
context of co-creating public value. Intermediaries translate the complex public sector information (i.e. legislation on the public spaces) and processes to the other groups in the system and allow connections to happen easier.

The context element refers to the settings the platforms operate within. In the digital economic era, resources and actors are embedded in networks. Therefore, the process of value creation is depending on the absorptive capacity and ability to operate in networks. The results of the empirical study on context dimension are illustrated in Table 4 below and discussed in the context of the framework below.

Table 4. Results of the context dimension

\begin{tabular}{|c|c|c|c|}
\hline $\begin{array}{l}\text { Name of the } \\
\text { platform }\end{array}$ & Code & $\begin{array}{l}\text { Number of partners } \\
\text { identified }\end{array}$ & Type of partners \\
\hline ABLE & $\mathrm{P} 1$ & 19 partners identified & $\begin{array}{l}\text { International organizations, NGOs, } \\
\text { associations }\end{array}$ \\
\hline Archmap.lt & $\mathrm{P} 2$ & 5 partners identified & $\begin{array}{l}\text { Governmental organizations, } \\
\text { business, NGOs }\end{array}$ \\
\hline asLietuvai.lt & P3 & No partners identified & $\mathrm{n} / \mathrm{a}$ \\
\hline Cultural cosmos & P4 & 10 partners identified & $\begin{array}{l}\text { Associations, municipalities, } \\
\text { governmental organizations, } \\
\text { business }\end{array}$ \\
\hline $\begin{array}{l}\text { Kelionès kultūros } \\
\text { keliais }\end{array}$ & P5 & 5 partners identified & NGOs, governmental entities \\
\hline Kurgyvenu.lt & P6 & No partners identified & $\mathrm{n} / \mathrm{a}$ \\
\hline mesDarom.lt & P7 & 20 partners identified & $\begin{array}{l}\text { Media organizations, NGOs, } \\
\text { business organizations, public } \\
\text { organizations }\end{array}$ \\
\hline Millenium & P8 & No partners identified & $\mathrm{n} / \mathrm{a}$ \\
\hline Nemasinis.lt & P9 & No partners identified & $\mathrm{n} / \mathrm{a}$ \\
\hline $\begin{array}{l}\text { pamatykLietuvoje. } \\
\text { lt }\end{array}$ & P10 & 6 partners identified & $\begin{array}{l}\text { Public organizations, NGOs, } \\
\text { governmental organizations }\end{array}$ \\
\hline $\begin{array}{l}\text { Transformatory } \\
\text { Association }\end{array}$ & P11 & 8 partners identified & International organizations, NGOs \\
\hline Tuk Tam & P12 & $\begin{array}{l}12 \text { partners identified } \\
\text { in the platform } \\
\text { content }\end{array}$ & $\begin{array}{l}\text { Business, NGOs, public } \\
\text { organizations }\end{array}$ \\
\hline Uspelite & P13 & $\begin{array}{l}12 \text { partners identified } \\
\text { in the platform } \\
\text { content }\end{array}$ & $\begin{array}{l}\text { International organizations, } \\
\text { business, NGOs, public } \\
\text { organizations }\end{array}$ \\
\hline
\end{tabular}

Source: developed by authors, 2017

Although the majority of the platforms aim to increase citizen engagement, the role of citizens is often limited to being users and contributors rather than partners (i.e. collaborators, experts contributing operant resources) in creation and management of ICT-enabled initiatives. In addition, the analysis of the platform connections with the 
external partners shows that majority of the projects have no external partners (or they do not declare the affiliations publicly). The role of contributor in the context of civic technologies is especially important. The platform activities often depend on the active engagement by the end users in contributing the content in form of ideas, opinions, reactions and support. However, the prevalence of this role is limited in the sample platforms. In most cases, citizens are expected to contribute in co-creating public value through the platforms. Other types of actors are not invited to contribute a content with the few exceptions. The results correspond with the central ideas of the conceptual framework which suggests that organizations no longer depend on the internal capacities to satisfy external needs. The sustainable initiatives and organizations are required to maintain relationships with other actors in the ecosystem (e.g. partners, competitors, governments and end users).

\section{Conclusions}

While traditional approaches to public engagement and governmental reforms remain relevant, this chapter focuses towards the growing potential of networked society to solve their social problems. It expands co-creation field and provide innovative framework to the citizens co-initiated, heavily technology supported, and systemsoriented co-creation approaches. A critical reflection on the co-creation practices is relevant to evaluate how digital enabled managerial and organisational solutions influence the quality of co-creation results, to understand what works by implementing the co-creations methods and what doesn't work and why. The nature of all these problems is interdisciplinary and have to be solved under the complex manner.

The technological advancements, innovative managerial strategies, and new forms of interaction lead to the constantly changing roles of the organizations and their customers. The concept of co-creation is seen as an evolving framework describing the shift from considering organizations as the definers of value to a more inclusive and collaborative processes involving end-users and other external actors. The use of a theoretical study of the literature on co-creation and empirical analysis of civic tech platforms allowed to identify main building blocks and attributes of co-creative digital initiatives in Bulgaria and Lithuania. Understanding co-creation in the public sector through ecosystem perspective requires to rethink of who can offer value in this space. The model suggests that the value emerges when a number of entities work collectively to create mutual benefits by granting access to one another's resources including people, technologies, organizations and information. Initiatives based on collaboration can only flourish through networks by including residents, communities, business, governmental institutions and other actors in the act of value generation.

The co-creation of value for the public through technologies encompasses many different interpretations and views depending researchers, developers, users, research areas and disciplines. Therefore, various parties are likely to hold different views and perceptions on the concept. The proposed model sheds dynamic ideas for future researches to further identify, conceptualize and understand the underlying theories and perspectives which strongly influence the previous, current, and future concept of cocreation. The model needs to be tested in additional cases to further verify its validity 
and usefulness in diverse settings by producing detailed longitudinal case studies. Further research could elaborate on the applicability of the framework in diverse setting - different countries. The maturity model of the ecosystem could be designed in order to provide more detailed guidelines for the actor involved in how to achieve the value. Additional work is needed to formulate measures and indicators of successful initiatives.

\section{References}

Akaka, M.A., Vargo, S.L., Lusch, R.F.: The complexity of context: a service ecosystems approach for international marketing. J. Int. Mark. Am. Mark. Assoc. 21(4), 1-20 (2013)

Aladalah, M., Lee, V.C.S.: Gov2.0: A Service Science Perspective. In Kankanhalli, A., Jones, A. B., Teo, T. (Eds.), PACIS 2015 Proceedings Atlanta, Georgia: Association for Information Systems (2015)

Alves, H.: Co-creation and innovation in public services. Serv. Ind. J. 33(7-8), 671-682 (2013). https://doi.org/10.1080/02642069.2013.740468

Armenakis, A.A., Bedeian, A.G.: Organizational change: a review of theory and research in the 1990s. J. Manag. 25(3), 293-315 (1999). https://doi.org/10.1177/014920639902500303

Bouchkhar, B.: Data sources on the Internet: towards a new and innovative solution. In: NTTS 2013, pp. 391-397 (2013)

Bradwell, P., Marr, S.: Making the Most of Collaboration: An International Survey of Public Service Co-design. Demos, London (2008)

Brown, L., Osborne, S.P.: Risk and innovation: public management review. Public Manag. Rev. 15(2), 186-208 (2012)

Cassia, F., Magno, F.: Public services co-production: exploring the role of citizen orientation. Int. J. Qual. Serv. Sci. 1(3), 334-343 (2009). https://doi.org/10.1108/17566690911004249

Clarke, R.Y.: Civic Tech Fuels U.S. State and Local Government Transformation. (2014). http:// www.accela.com/images/resources/whitepaper/idc-civic-tech-report.pdf

Cobo, C.: Networks for citizen consultation and citizen sourcing of expertise. Contemp. Soc. Sci. 7(3), 283-304 (2012). https://doi.org/10.1080/21582041.2012.683445

Cruickshank, P., Deakin, M.: Co-design in Smart Cities: a guide for municipalities from Smart Cities, 1-36 (2011). http://researchrepository.napier.ac.uk/5659/

Emerson, K., Nabatchi, T., Balogh, S.: An integrative framework for collaborative governance. J. Public Adm. Res. Theory 22(1), 1-29 (2011). https://doi.org/10.1093/jopart/mur011

Galvagno, M., Dalli, D.: Theory of value co-creation: a systematic literature review. Manag. Serv. Qual. Int. J. 24(6), 643-683 (2014). https://doi.org/10.1108/msq-09-2013-0187

Giest, S., Koene, A., Vallejos, E.P., Pitkänen, O., Fosci, M.: Online spaces for urban citizen engagement: a comparison of civic apps. In: Data for Policy Conference, pp. 1-6 (2016)

Goda, K., Kijima, K.: Modeling service ecosystems innovation. J. Bus. Manag. Sci. 3(3), 85-91 (2015). https://doi.org/10.12691/jbms-3-3-1

Gouillart, F., Hallett, T.: Co-creation in Government. Stanford Social Innovation Review, pp. 116, Spring 2015

Hamann, R.: Strategic change in organisations and governance systems in response to complex socio-ecological problems in Southern Africa. Synoptic Strategy Outline, pp. 1-6, November 2009 
Harrison, T.M., Pardo, T.A., Cook, M.: Creating open government ecosystems: a research and development agenda. Futur. Internet 4(4), 900-928 (2012). https://doi.org/10.3390/fi4040900

Hepburn, P.: An evaluation of the "helping hands-co-creation of a digital application for elderly people" project, March 2015

IfM and IBM.: Succeeding through service innovation. Symposium A Quarterly Journal. In: Modern Foreign Literatures. Cambridge, United Kingdom: University of Cambridge Institute for Manufacturing (2008)

Jabareen, Y.: Building a conceptual framework: philosophy, definitions, and procedure. Int. J. Qual. Methods 8, 49-62 (2009). https://doi.org/10.2522/ptj.20100192

Jacobsen, E.O.: Public spaces support social engagement and then provide the necessary buy-in to sustain moral engagement as well, 1-21 (2016)

Jan, P.T., Lu, H.P., Chou, T.C.: Measuring the perception discrepancy of the service quality between provider and customers in the Internet Protocol Television industry. Total Qual. Manag. Business Excel. 23(7-8), 981-995 (2012)

Krimmer, R., Kalvet, T., Toots, M., McBride, K.: OpenGovIntelligence: Fostering Innovation and Creativity in Europe through Public Administration Modernization towards Supplying and Exploiting Linked Open Statistical Data (2016)

Linders, D.: From e-government to we-government: defining a typology for citizen coproduction in the age of social media. Gov. Inf. Q. 29(4), 446-454 (2012)

Lönn, C.-M., Uppström, E.: Core aspects for value co-creation in public sector. In Americas Conference on Information Systems , Puerto Rico, pp. 1-12 (2015)

Lusch, R.F., Vargo, S.L., Wessels, G.: Toward a conceptual foundation for service science: contributions from service-dominant logic. IBM Syst. J. 47, 5-14 (2008)

McNutt, J.G., et al.: The diffusion of civic technology and open government in the United States. Inf. Polity 21(2), 153-170 (2016). https://doi.org/10.3233/ip-160385

Meijer, A.J., Koops, B.-J., Pieterson, W., Overman, S., Tije, S.T.: Government 2.0: key challenges to its realization. Electron. J. E-Gov. 10(1), 59-69 (2012)

Meynhardt, T., Chandler, J.D., Strathoff, P.: Systemic principles of value co-creation: synergetics of value and service ecosystems. J. Bus. Res. 69(8), 2981-2989 (2016). https://doi.org/10. 1016/j.jbusres.2016.02.031

Pozzebon, M., Diniz, E.H.: Theorizing ICT and society in the Brazilian context: a multilevel, pluralistic and remixable framework. Braz. Adm. Rev. 9(3), 287-307 (2012). https://doi.org/ 10.1590/s1807-76922012000300004

Skaržauskienè, A., et al.: Social Technologies and Collective Intelligence. Mykolas Romeris University, Vilnius (2015)

Skidmore, P., Bound, K., Lownsbrough, H.: Community Participation: Who Benefits?. Joseph Rowntree Foundation, York, UK (2006)

Stembert, N., Mulder, I.J.: Love your city! An interactive platform empowering citizens to turn the public domain into a participatory domain, (Section 4) (2012)

Sterrenberg, G.: A conceptual framework for evaluating e-government systems success: a service ecosystem approach. In: 50th Hawaii International Conference on System Sciences, pp. 2529-2538 (2017)

Uppström, E.: The Promise of Public Value Co-creation in Open Government. DSV Report Series. Stockholm. (2014). http://www.diva-portal.org/smash/get/diva2:697081/FULLTEXT03

Voorberg, W., Bekkers, V., Tummers, L.: The keys to successful co-creation: an explanation using causal proces tracing. EGPA Conference, 320090(320090), pp. 1-32 (2014). http:// repub.eur.nl/pub/76034

Warburton, D., Wilson, R., Rainbow, E.: Making a Difference: A guide to Evaluating Public Participation in Central Government. London (2010). http://www.involve.org.uk/evaluation 
Open Access This chapter is licensed under the terms of the Creative Commons Attribution 4.0 International License (http://creativecommons.org/licenses/by/4.0/), which permits use, sharing, adaptation, distribution and reproduction in any medium or format, as long as you give appropriate credit to the original author(s) and the source, provide a link to the Creative Commons license and indicate if changes were made.

The images or other third party material in this chapter are included in the chapter's Creative Commons license, unless indicated otherwise in a credit line to the material. If material is not included in the chapter's Creative Commons license and your intended use is not permitted by statutory regulation or exceeds the permitted use, you will need to obtain permission directly from the copyright holder. 